\title{
EXPERIMENTS ON THE ELASTICITY OF THE VOCAL CORDS
}

\author{
DAMSTÉ, P.H., M.D. and WIENEKE, G.H., PH.D. \\ Afdeling Foniatrie, Universiteits KNO-Kliniek, \\ Catharijnesingel 101, Utrecht, Nederland
}

\section{SUMMARY}

Regulation of vocal pitch occurs by changes in the length and tension of the vocal folds. Because the Young's modulus of the vocal cord ligament could be a factor which determines the difference between male and female voices, this was made an object of research. No differences could be shown. Some of the problems and the limited accuracy of these experiments are reviewed.

\section{OPSOMMING}

Beheer van stemtoonhoogte vind plaas deur veranderinge in the lengte en spanning van die stemvoue. Aangesien Young se modulus van die stemlipligament 'n faktor kan wees wat die verskil tussen manlike en vroulike stemme bepaal, was dit die onderwerp van navorsing. Geen verskille word aangetoon nie. Sommige van die probleme en die beperkte akkuraatheid van hierdie eksperimente word bespreek.

When the pitch of the voice rises, the length of the vocal cords increases. All specialists in voice agree with this, no matter how they differ in other opinions. The mechanism by which the length of the vocal cords increases is well known; the backward turning of the cricoid cartilage in respect to the thyroid by the pull of the cricothyroids increases the distance from the arytenoids to the farthest attachment point of the vocal cords. The amount of stretch of the vocal folds which can be effected by this physiological mechanism was specified by Sonninen ${ }^{12}$ with the help of $\mathrm{X}$-rays. From this research came a paper on the lengthening mechanism, more accurate than that given by $R$. Schilling ${ }^{10}$ in 1940.

Van den Berg ${ }^{5}$ proposed by means of experiments with cadaver larynges, that the vocal cords can stretch to a maximum of $30 \%$ of their original length. In addition, the tension (in other words the elasticity modulus) increases approximately proportional to the traction exercised on the tissue. Falsetto tones are produced by the fully stretched position of the vocal ligament and conus elasticus. These tones are at one end of the vocal register scale, and at the other end are the tones of the chest register, the normal speaking voice of man. This type of voice is generated by the completely relaxed and supple vocal folds, in which all parts participate, in the vibration. For a melodious speaking voice, 
and of course above all for singing, it is important that higher tones are produced in a mixed or a middle register. In this case the tensing of the ligament by the cricothyroid is combined with the tensing and shortening of the muscles by contraction of the internal and external thyroarytenoids. Thus the vibration of the ligament remains coupled with that of the muscle mass, which gives rise to the full tone of the normal register. In falsetto register the vibration is not transmitted to the whole vocal fold, only the medial edge vibrates. This results in a weak, thin tone. The voice can be voluntarily controlled to a great extent, and any individual can make a large variety of vocal sounds.

From just the sound of the voice it is possible to form an idea of the person, his character and his mood. One has, as it were, an acoustic face, from the sound of the voice. Damage to the voice is just as disturbing as a facial scar. A woman with a voice which has become masculine through the use of androgens, has suffered an irreparable mutilation. Her acoustic impression has lost a great deal of prettiness. She can shave or wax away her facial hair, but her cracking baritone cannot be hidden, except by not going out or by keeping quiet.

The problem of virilisation of the voice became noticed in the years after 1960 through the introduction of anabolic steroids. ${ }^{1,2,6,9}$ It is not possible to guess how many women have been made victims by the unchecked use of these drugs. It is still a real problem. When one has seen it once, it is apparent that it is not rare, particularly the early stages of voice virilisation. In the early stages the symptoms are not so obvious. Characteristic symptoms are: unsteady vocal pitch which wavers between two timbres; a light and dark one. It is the lack of control which gives the voice a subjective strange sensation. The range is not decreased, rather the lower range increased, and the higher tones less well controlled than before. This is only noticed by women who sing.

Vocal cord oedema comes especially into consideration for differential diagnosis; the pitch range in the higher tones is severely limited through this. However this is not the case in the early stages of virilisation. Mirror examination shows a great difference. In vocal cord oedema there is a widening of the vocal folds, which are lighter coloured. Laryngeal stroboscopy shows greater vibration amplitude and a widening of the wavecrest. There is frequently nothing special to see in virilised vocal cords. Only in a later stage is there sometimes a change in colour, to a dark yellow.

What change in the vocal folds is responsible for the change of voice in the woman whose voice becomes masculine? That is the question which many have put, and which has many different answers. Some have sought the cause outside the larynx, in timing of conduction of impulses in the nervous system. We can forget this possibility, as it is based on a most improbable theory of vocal cord vibration. Serious thought has been given to the opinion that the change is due to a change in muscle-tissue in the vocal folds, the enlargment being directly caused by the anabolic* effect of testerone and other steroid compounds. Another opinion is that change in the mucous membrane causes the change in voice timbre. Perello ${ }^{9}$ has studied a section from a mutated

\section{${ }^{*}$ By this is meant the property to promote the synthesis of muscle protein.}


larynx and reports a thickening of the middle layer of epithelium. In the same article he gives the increase in volume and power of the thyroarytenoids and the inspiration muscles as causes of the deepening of the voice. In differential diagnosis of vocal cord oedema, it is possible to find arguments which make the thickening of the epithelium as one of the causes of a voice change less probable. It is also known that steroids, to which the androgen hormone belongs, have an effect on the composition of connective tissue. Since the connective tissue in the vocal folds (coni elastici and vocal cord ligaments) greatly determines the sort of voice and its quality, the hypothesis is that changes in this shall account for masculine voice in women. Some physio-chemical arguments have been discussed by Damsté. ${ }^{7}$

\section{EXPERIMENTS}

In 1963-1964, we studied the possibility of whether the elasticity of the connective tissue in the edge of the vocal cords, could be determined by measuring the elasticity. Experiments were carried out on a score of larynges. The results were in many cases not completely reliable due to complicating circumstances and that is the reason why the work has not been published until now. On closer examination of the data we feel that it is still useful to publish the method used, and a few of the results, as a guide and a warning to poténtial researchers.

The plan was to determine the Young's modulus of a satisfactorily large number of vocal cords from men, women, women with masculine voices and possibly children and to see if the values of the Young's modulus in the four groups were significantly different.

\section{METHOD}

The elongation of the vocal cord and the force was measured with the apparatus shown in Figure 1. The ends of the specimen were clamped. One end was fixed to the support and one to the arm of a lever made from a light and stiff hollow pipe. On the other side of the axis of rotation the end of a spring was attached. The spring could be stretched by displacing the other end by a nylon thread which is wound round an axis behind the black knob (below right in Figure 1). The force exerted by the spring is indicated in grams on a gauged scale. The long arm of the balance indicates the elongation of the specimen in tenths of a millimeter.

\section{PROCEDURE}

An experiment with forces from 0-60 grams in 5 grm intervals was done within a minute, the time necessary to write or to dictate the numbers. More time was necessary for the preparation of the specimens. To get a solid attachment of the ligament a piece from the thyroid cartilage and from the arytenoid was taken with it. The measurement was done after the specimens had lain in a physiological salt solution for ten minutes. Measurements with more or less dried out specimens were not reliable. 


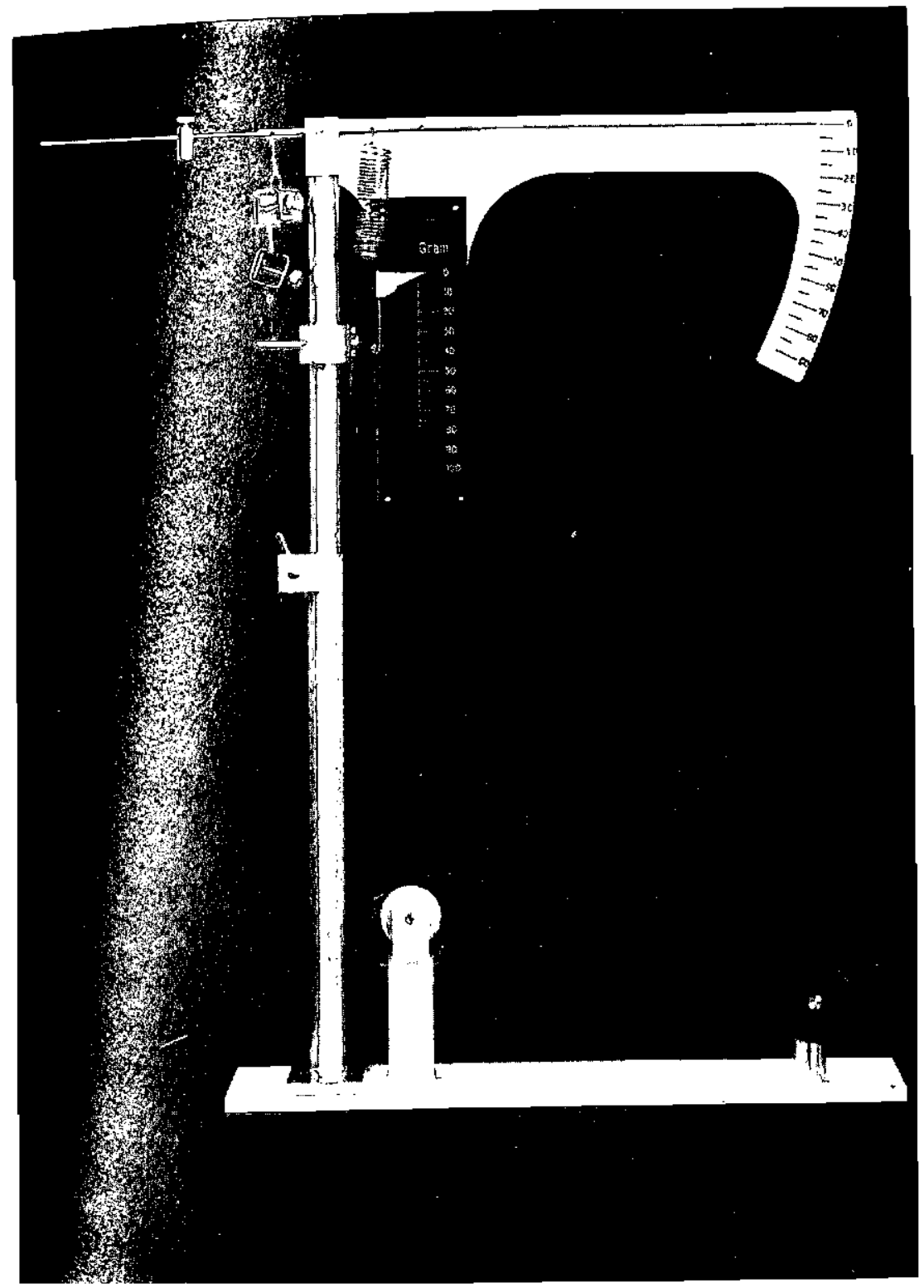

Figure 1. The apparatus with which the stress-strain curves of the vocal cord were measured. The vocal cord was fixed on the left side with two clamps. In the middle is the scale for force, to the right the scale for increase in length. See text (methods) for further explanation. 


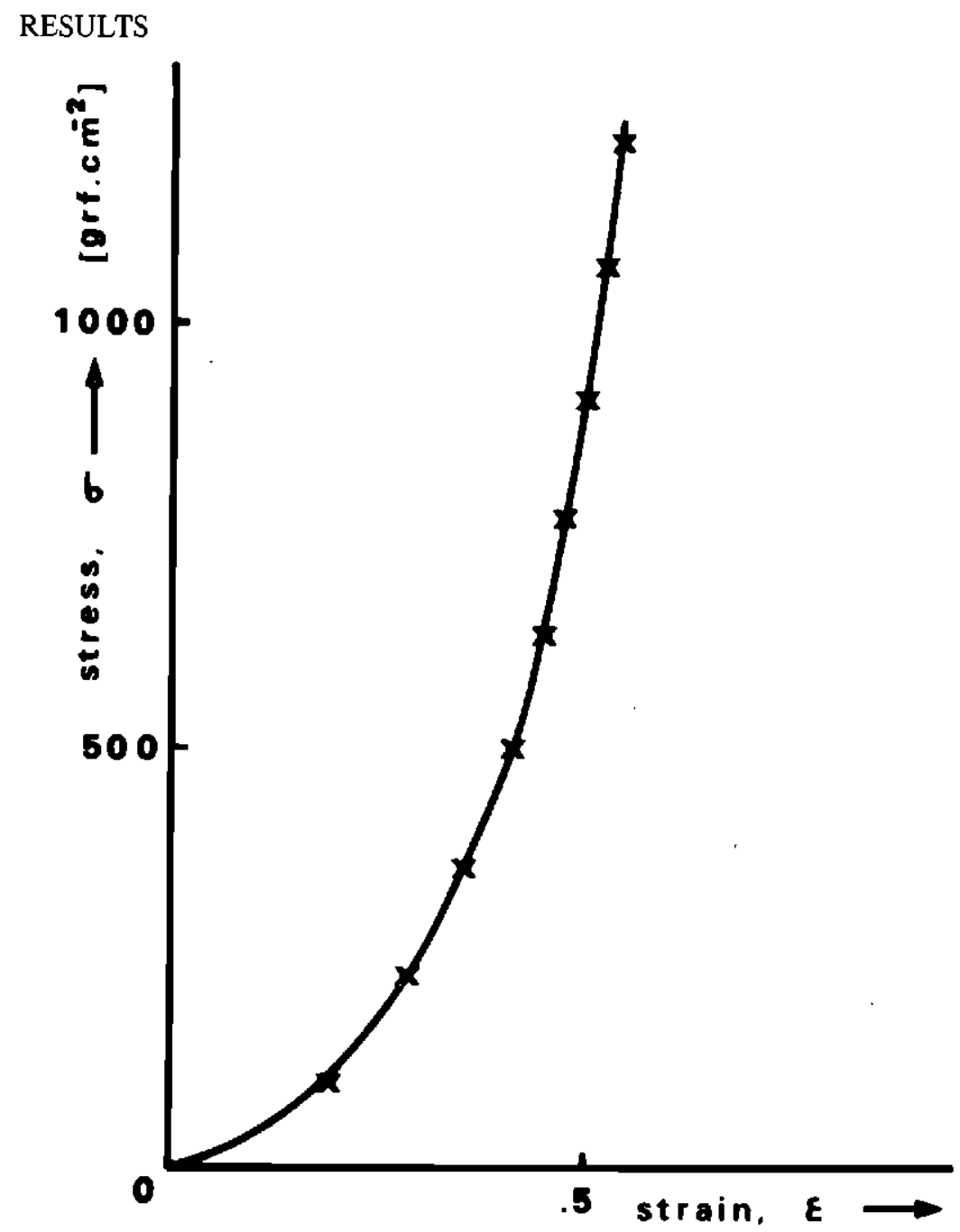

Figure 2. Tension 6 as a function of the elasticity $\varepsilon$ of the right vocal cord from a woman who died at 40 years.

An example of the results is shown in figure 2. The stress (force/area of the cross-section) is given against the strain (increase in length/length with 0 gram force). The cross-section of the vocal cord was calculated from the weight with the assumptions that (a) the area of the cross-section is equal over the whole length (b) the mass density of the tissue is $1 \mathrm{grm} . \mathrm{cm}^{-3}$. In these preliminary measurements the results of 8 male vocal cords and 10 female were considered. In all cases the stiffness (Young's modulus measured as a slope on the curve: $\Delta 6 / \Delta \varepsilon$ ) increased greatly with increasing strain (to $15 *$ ). The value 
of the strain, above which the curves rise steeply, shows noticeably great differences. These differences were clearly correlated with the age of the patient on death. The relation between the age and the strain where the Young's modulus is one half of the maximum value measured in the experiment is shown in figure 3. Also, the Young's modulus at the beginning of the

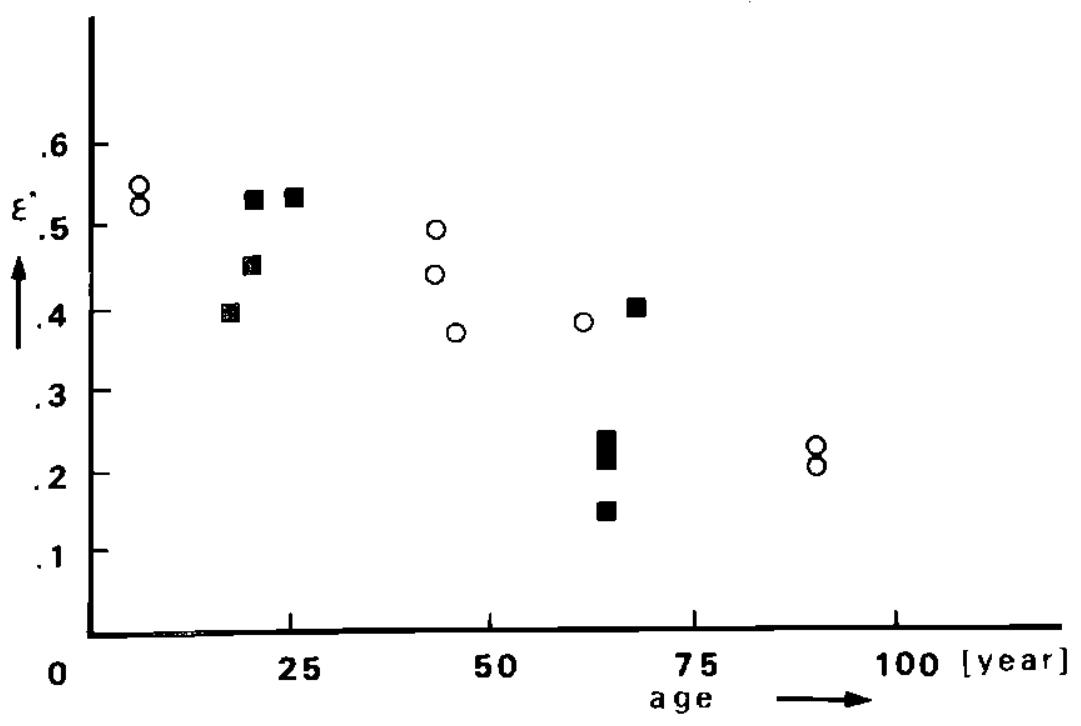

Figure 3. Value of the elasticity $\varepsilon^{ \pm}$at which the Young's modulus of the vocal cord is equal to half the maximum measured value set out against the age of the person at death. Shaded blocks $=$ male, Open circles $=$ female, Correlation co-efficient $=0.8$.

curve (0-5 grf) shows the dependance on age. For example the Young's modulus measured from a girl of 6 years was $350 \mathrm{grf} . \mathrm{cm}^{-2}$ and from a woman of 40 years $550 \mathrm{grf} . \mathrm{cm}^{-2}$. The maximum error of the apparatus is about $20 \%$ in this range. In the normal voice range the elasticity at small stresses will be important. The Young's modulus in the range of strain less than $25 \%$ does not show significant differences in vocal cords from males and females without masculine voice change. This is partly due to the lack of precision of the measurements but mainly to the influence of the age of the person.

\section{CONCLUSIONS}

From these measurements no significant difference between the Young's modulus for low stress values in males or females could be determined. Consequently no conclusion can be drawn as to how far masculine changes of the female voice are a result of change in the Young's modulus. 
Possibly age has a greater influence on the vocal cords than use of drugs. We must first have a better insight into the changes in the vocal apparatus due to age, before it can be concluded that the changes in voice with the use of virilising drugs are due to changes in elasticity. It seems advisable to investigate other factors which have an effect on these changes. One can think of the increase in the mass of the intrinsic laryngeal muscles.

The accuracy of the elasticity modulus is one of the obstructions to interpret low strain $(<25 \%)$ values. In view of the discovered differences the maximum error had to be smaller than $40 \mathrm{grf} . \mathrm{cm}^{-2}(7 \%)$. To achieve this, the measuring apparatus had to meet the following requirements: The zero length must be measured with an accuracy of $\pm 0.2 \mathrm{~mm}$; the elongation with $\pm 0.02 \mathrm{~mm}$; the force with $\pm 0.05 \mathrm{grf}$; the weight with $\pm 0.5 \mathrm{mgr}$. maximum error. This includes the uncertainties with regard to the true length of the vocal cord, the varying cross-section and deviations in mass density. In the statistic analysis the effect of age has to be taken into account.

\section{DISCUSSION}

The conclusions do not confirm our hypothesis that the Young's modulus in men and women with virilised voices have lower values than in normal women. Therefore they are not in agreement with the results of Bauer ${ }^{4}$ which did confirm this hypothesis. He described a clear relationship between the Young's modulus and the sex (ratio 2:1) and could also discern the effects of voice mutating substances. Bauer calculates the values for the Young's modulus at a $50 \mathrm{grm}$ weight. According to our measurements the tissue is then already in the range of a high Young's modulus, at which it probably does not reach during normal voice use. The value of the Young's modulus according to Bauer, is somewhat smaller than that found by us: $600-1300 \mathrm{grf} . \mathrm{cm}^{-2}$ against $1800-4500 \mathrm{grf}_{\mathrm{cm}}-2$ measured with a stress of $50 \mathrm{grm}$.

\section{REFERENCES}

1. Arndt, H.J. (1963): Stimmschäden bei Frauen durch androgene und anabole Hormone. Deutsche Med. Woch. 88: 2336-2339.

2. Bauer, H. (1963): Die Beeinflussung der weiblichen Stimme durch androgene Hormone. Folia Phoniatrica 15: 264-268.

3. Bauer, H. und König, W. (1967): Physikalische und histologische Untersuchungen am normalen und einem weiblichen virilisierten Kehlkopf. Arch. Ohr. Nas.-Kehlk. Heilk. 188: 358-363.

4. Bauer, H. (1968): Die Beziehungen der Phoniatrie zur Endokrinologie. Folia Phoniatrica 20: 387-393.

5. Berg van den, Jw. (1960): Current Probl. Phoniat. Logop., Karger, BaselNew York 19-34.

6. Damsté, P.H. (1964): Virilisation of the voice due to anabolic steroids. Folia Phoniatrica 16: 10-18.

7. Damsté, P.H. (1964): Virile changes in the voice induced by androgens. Excerpta Medica Intern. Congress 85: 158-160. 
8. Damsté, P.H. (1967): Voice change in adult women caused by virilizing agents. Journ. of Speech and Hearing Disorders, 32: 126-132.

9. Perello, J. (1964): Virilizacion de la laringe femenina. Acta O.R.L. Iber.Amer. XV, 2: 139-141.

10. Schilling, R. (1940): Uber den Spannungsmechanismus der Stimmlippen Hals-Nasenund Ohrenarzt 31: $11^{\prime 2} 2$.

11. Sonninen, A. (1956): The role of the external laryngeal muscles in length adjustment of the vocal cords in singing. Acta Otolaryngol Suppl. 130 , Stockholm.

12. Sonninen, A. (1962): Paratasis-gram of the vocal folds and the dimensions of the voice. Proc. 4th Intern. Congr. Phonetics (Helsinki), Ed. Mouton, Den Haag 250-258.

\section{FOR ALL YOUR MEDICAL BOOK AND JOURNAL REQUIREMENTS}

CONSULT

\section{THE SPECIALISTS}

\section{P. B. MAYER}

902 Norwich House

Heerengracht CAPE TOWN

Telephone 2-9231 